\title{
Diagnostic and prognostic significance of inflammatory parameters in acute diverticulitis: A retrospective cohort study
}

\author{
Süleyman Kargın, M.D., (i) Yusuf Tanrıkulu, M.D.
}

Department of General Surgery, KTO Karatay University Faculty of Medicine, Konya-Turkey

\begin{abstract}
BACKGROUND: The optimum biochemical or hematological marker to determine diagnosis and severity of acute diverticulitis has not been established. We aimed to compare the utility of hematological parameters in the diagnosis and severity of acute diverticulitis.

METHODS: Sixty-nine patients in diverticular disease (acute diverticulitis and diverticulosis subgroups) and 36 patients in control group were included in the study. The biochemical analysis performed at the time of diagnosis included white blood cell, mean platelet volume, neutrophil count, platelet count (PLT), C-reactive protein, and calculation of neutrophil count/lymphocyte and PLT/lymphocyte ratios. Patients in the diverticulitis group were divided into four stages according to the Hinchey classification based on abdominal CT findings.
\end{abstract}

RESULTS: The mean platelet-lymphocyte ratio in the diverticulitis and diverticulosis groups was significantly lower than that in the control group $(p<0.05)$. The best sensitivity and specificity values to distinguish acute diverticulitis and diverticulosis were $63.64 \%$ and $72.22 \%$ for the neutrophil-lymphocyte ratio (NLR) at a cutoff value of 2.78 and above and $30.30 \%$ and $86.11 \%$ for the platelet-lymphocyte ratio at a cutoff value of 87.46 and above. The diagnostic accuracy rates to distinguish between the diverticulitis and the control groups that the best sensitivity and specificity values were found to be NLR at a cutoff value of II.55 and above and $100 \%$ and $100 \%$ for the platelet-lymphocyte ratio at a cutoff value of 12.28 and above. The NLR values were significantly lower in patients with Hinchey Stage I disease than those in patients with Stages 2 and 3 disease (respectively, $p=0.003$ and $p=0.006$ ).

CONCLUSION: NLR and platelet-lymphocyte ratio can serve as useful biomarkers for the differential diagnosis and severity in acute diverticulitis.

Keywords: Acute diverticulitis; diverticulosis; neutrophil-lymphocyte ratio; platelet-lymphocyte ratio.

\section{INTRODUCTION}

Diverticular disease of the colon (DDC) is a common disease in Western societies and is increasing in incidence. [1,2] Although most patients with DDC are asymptomatic, $10-25 \%$ of these patients may have acute diverticulitis and other complications such as abscess, fistula, and perforation. [3] Colonoscopy is used to diagnose DDC, but computed tomography (CT) is used for both the diagnosis and the staging of the disease after clinical evaluation of acute diverticulitis. ${ }^{[4,5]}$ Because of acute diverticulitis is uncomplicated in $90 \%$ of the patients and concerns regarding radiation exposure, the use of imaging is curtailed, as it is believed that there will be no effect on the treatment decision. ${ }^{[6]}$ Unfortunately, clinical evaluation alone is insufficient for an accurate diagnosis. Therefore, clinical diagnosis should be supported by additional tests. The optimum biochemical or hematological marker to determine disease severity in the diagnosis of diverticular disease or acute diverticulitis has not been established.

The neutrophil-lymphocyte ratio (NLR) is a useful index for differential diagnosis or prognostic prediction of diseas-

Cite this article as: Kargın S, Tanrıkulu Y. Diagnostic and prognostic significance of inflammatory parameters in acute diverticulitis: A retrospective cohort study. Ulus Travma Acil Cerrahi Derg 2021;27:325-330.

Address for correspondence: Süleyman Kargın, M.D.

KTO Karatay Üniversitesi Tıp Fakültesi, Genel Cerrahi Anabilim Dalı, Konya, Turkey

Tel: +90332 - 221 8080 / 206 I E-mail: drs.kargin@hotmail.com

Ulus Travma Acil Cerrahi Derg 2021;27(3):325-330 DOI: 10.14744/tjtes.2020.92068 Submitted: 12.03.2020 Accepted: 04.05.2020

Copyright 2021 Turkish Association of Trauma and Emergency Surgery 
es, because it is easily calculated and is known to provide information about inflammatory activity. ${ }^{[7-1 I]}$ White blood cell count (WBC) and C-reactive protein (CRP) values have been suggested to help distinguish between complicated and uncomplicated acute diverticulitis. ${ }^{[2-14]}$ However, the use of laboratory results for diagnosis of DDC has not been a focus of research. The role of the NLR in the diagnosis of acute diverticulitis has been evaluated in only two studies. ${ }^{[15,16]}$

In this study, we aimed to compare the utility of hematological parameters in the diagnosis of DDC and the prediction of the disease course and to determine additional parameters that might aid in the diagnosis.

\section{MATERIALS AND METHODS}

\section{Study Plan and Patient Groups}

Local ethics committee approval (approval number 2019/06) was obtained for the study, which was performed retrospectively. Patients diagnosed with diverticulosis and acute diverticulitis who were treated and followed up at a tertiary university hospital between January I, 2014, and December 31,2019 , were included in the study. A control group was formed from healthy individuals with no inflammatory pathology who applied to the outpatient clinic for a check-up program and referred with non-specific abdominal pain to general surgery clinic. Patient data were accessed from the archive files in the hospital automated system. The diagnosis of diverticulosis was based on colonoscopic imaging results, whereas the diagnosis of diverticulitis was based on abdominal CT reports. Patients in the diverticulitis group were divided into four stages according to the Hinchey classification based on abdominal CT findings. ${ }^{[17]}$ The biochemical analysis performed at the time of diagnosis included WBC $\left(10^{9} / \mathrm{L}\right)$, mean platelet volume (MPV, f L), platelet count (PLT, $\left.10^{\circ} / \mathrm{L}\right)$, and CRP $(\mathrm{mg} / \mathrm{dL})$ values and calculation of neutrophil count/ lymphocyte count (NLR) and platelet count/lymphocyte count (PLR) ratios. All of the samples for the biochemical analysis were taken before antibiotic treatment. In addition, the need for surgery, length of the hospital stay, and complication data for the patients hospitalized for diverticulitis were recorded.

\section{Statistical Analysis}

Data were analyzed by SPSS (Windows 22.0) packet program. Numerical variables were given as mean \pm standard deviation and Student's t-test was used to compare the means of two independent groups. Non-continuous variables were compared using the Chi-square test. Receiver operating characteristic (ROC) curve analysis was used to detect the optimal cutoff levels for the MPV, WBC, CRP, NLR, and PLR. Specificity, sensitivity, positive predictive value, negative predictive value, and area under the curve (AUC) were calculated for all markers and ratios. In addition, Youden's index (YI) was calculated to optimize the overall accuracy.

\section{RESULTS}

There were 33 patients in the diverticulitis group, 36 patients in the diverticulosis group, and 36 patients in the control group. There were no significant differences in age and gender among the three groups $(p>0.05)$. The demographic data of the groups are given in Table I. In the diverticulitis group, 19 patients (57.6\%) with diverticulitis required hospitalization and the average length of hospitalization was $2.27 \pm 2.24$ days. The number of patients with diverticulitis who required surgery was 7 (21.2\%). Cecal diverticulitis was observed in two patients and bladder fistula was seen in two patients. One patient who had Hinchey Stage 3 was dead during the pre-operative period. There were no hospitalizations or complications in the diverticulosis and control groups (Table I).

The distribution of the laboratory parameters among the groups is given in Table 2 . There was a statistically significant difference between the diverticulitis group and the other two groups for the mean WBC $(p=0.001$ compared to the diverticulosis group and $p=0.004$ compared to the control group). There was also a statistically significant difference between the diverticulitis group and the other two groups for the mean CRP ( $p<0.001$ compared to the other groups). In addition, the mean CRP in the diverticulosis group was significantly greater than that in the control group $(p<0.00 \mathrm{I})$. The mean MPV in the control group was significantly greater than those in the other two groups $(p<0.001)$. The mean NLR in the diverticulosis group was significantly lower than those in

Table I. The demographic data of all groups

\begin{tabular}{lccc}
\hline & $\begin{array}{c}\text { Diverticulitis group } \\
(\mathbf{n}=\mathbf{3 3})\end{array}$ & $\begin{array}{c}\text { Diverticulosis group } \\
(\mathbf{n = 3 6 )}\end{array}$ & $\begin{array}{c}\text { Control group } \\
(\mathbf{n}=\mathbf{3 6})\end{array}$ \\
\hline Average age (years) & $55.97 \pm 16.42$ & $58.64 \pm 14.75$ & $51.16 \pm 12.62$ \\
Gender (female/male), $n$ & $18 / 15$ & $20 / 16$ & $15 / 21$ \\
Mean Hinchey's Score & $1.61 \pm 0.86$ & 0 & 0 \\
Hospitalization required, $\mathrm{n}(\%)$ & $19(57.6)$ & 0 & 0 \\
Duration of hospitalization (days) & $2.27 \pm 2.24$ & 0 & 0 \\
Operation required, $\mathrm{n}(\%)$ & $7(21.2)$ & 0 & 0 \\
\hline
\end{tabular}


the other two groups $(p=0.009$ compared to the diverticulitis group and $p=0.002$ compared to the control group). The mean PLR in the diverticulitis and diverticulosis groups was significantly lower than that in the control group $(p=0.006$ for the diverticulitis and $p=0.002$ for the diverticulosis groups, Table 2).

The diagnostic accuracy rates of the various laboratory parameters to distinguish between the diverticulitis and diverticulosis groups are given in Table 3 and Figure I. The best sensitivity and specificity values were $66.67 \%$ and $77.78 \%$ for the WBC at a cutoff value of 9450 and above, $81.82 \%$ and $83.33 \%$ for the CRP at a cutoff value of 3 and above, $84.85 \%$ and $30.56 \%$ for the MPV at a cutoff value of 8.16 and above, $63.64 \%$ and $72.22 \%$ for the NLR at a cutoff value of 2.78 and above, and $30.30 \%$ and $86.11 \%$ for the PLR at a cutoff value of
87.46 and above. According to the ROC curve, the AUC values for the same parameters were found to be $0.730,0.793$, $0.56 \mathrm{I}, 0.682$, and $0.5 \mathrm{I} 6$, respectively (Fig. I).

The diagnostic accuracy rates to distinguish between the diverticulitis and the control groups for the same parameters are given in Table 4 and Figure 2. The best sensitivity and specificity values were found to be $66.67 \%$ and $72.22 \%$ for the WBC at a cutoff value of 9390 and above (YI: 0.389), 90.91\% and $97.22 \%$ for the CRP at a cutoff value of I.I and above (YI: 0.881 ), $69.70 \%$ and $91.67 \%$ for the MPV at a cutoff value of 7.88 and above (YI: 0.707 ), $100 \%$ and $0 \%$ for the NLR at a cutoff value of $1 \mathrm{I} .55$ and above, and $100 \%$ and $100 \%$ for the PLR at a cutoff value of 12.28 and above (YI: I). According to the ROC curve, the AUC values of the same parameters were $0.702,0.926,0.843,1.000$, and 1.000 , respectively.

Table 2. Laboratory data for all groups

\begin{tabular}{|c|c|c|c|}
\hline & Diverticulitis group $(n=33)$ & Diverticulosis group & Control group $(n=36)$ \\
\hline White blood cell count $\left(\times 10^{9} / \mathrm{L}\right)$ & $10491.52 \pm 3633.16^{*} \#$ & $98|3.61 \pm 77| 0.7 \mid$ & $8366.11 \pm 2046.95$ \\
\hline C-reactive protein $(\mathrm{mg} / \mathrm{dL})$ & $16(0-2 \mid 4.38)^{\mathrm{a}, \mathrm{b}}$ & $2(0.1-40.27)^{c}$ & $0.30(0-2.10)$ \\
\hline Mean platelet volume $(\mathrm{fL})$ & $7.35 \pm 1.24$ & $7.68 \pm 1.36$ & $8.81 \pm 0.88^{€}$ \\
\hline Neutrophil-lymphocyte ratio & $3.11(1.44-11.55)$ & $1.99(0.93-10.26)^{\alpha, \beta}$ & $3.28(1.38-12.28)$ \\
\hline Platelet-lymphocyte ratio & $103.80(57.18-298.05)$ & $109.99(72.54-383.33)$ & $152.44(69.17-4 \mid 4.47)^{£, *}$ \\
\hline
\end{tabular}

" $p=0.001$ versus diverticulosis group, ${ }^{\#} p=0.004$ versus control group, ${ }^{a, b} p<0.001$ versus other groups, ${ }^{c} p<0.001$ versus control group, $\epsilon_{p}<0.001$ versus other groups, ${ }^{\alpha} \mathrm{p}=0.009$ versus diverticulitis group, ${ }^{\beta} \mathrm{p}=0.002$ versus control group, ${ }^{\ell} \mathrm{p}=0.006$ versus diverticulitis group, ${ }^{\neq} \mathrm{p}=0.002$ versus Diverticulosis group.

Table 3. Overall accuracies afforded by the laboratory parameters used to distinguish patients with diverticulitis from patients with diverticulosis (\%)

\begin{tabular}{lcccccc}
\hline & Sensitivity & Specificity & PPV & NPV & Cut-off & Youden's Index \\
\hline White blood cell count & 66.67 & 77.78 & 73.30 & 71.80 & 9450 & 0.445 \\
C-reactive protein & 81.82 & 83.33 & 81.80 & 83.33 & 3 & 0.652 \\
Mean platelet volume & 84.85 & 30.56 & 52.80 & 68.80 & 8.16 & 0.154 \\
Neutrophil-lymphocyte ratio & 63.64 & 72.22 & 67.70 & 68.40 & 2.78 & 0.359 \\
Platelet-lymphocyte ratio & 30.30 & 86.11 & 66.70 & 57.40 & 87.46 & 0.164 \\
\hline
\end{tabular}

NPV: Negative predictive value; PPV: Positive predictive value.

Table 4. Overall accuracies afforded by laboratory parameters used to distinguish patients with diverticulitis from control subjects (\%)

\begin{tabular}{lcccccc}
\hline & Sensitivity & Specificity & PPV & NPV & Cut-off & Youden's Index \\
\hline White blood cell count & 66.67 & 72.22 & 68.80 & 70.30 & 9390 & 0.389 \\
C-reactive protein & 90.91 & 97.22 & 96.80 & 92.10 & 1.1 & 0.881 \\
Mean platelet volume & 69.70 & 91.67 & 88.50 & 76.70 & 7.88 & 0.707 \\
Neutrophil-lymphocyte ratio & 100 & 0 & 100 & 100 & 11.55 & 0 \\
Platelet-lymphocyte ratio & 100 & 100 & 100 & 100 & 12.28 & 1.000 \\
\hline
\end{tabular}

NPV: Negative predictive value; PPV: Positive predictive value. 




Figure 1. The diagnostic accuracy rates of the various laboratory parameters to distinguish between the diverticulitis and diverticulosis groups.

The distribution of laboratory parameters according to Hinchey's stage in the diverticulitis group is given in Table 5. There were no significant differences among the various stages for WBC, CRP, and MPV values. The NLR values were significantly lower in patients with Hinchey Stage I disease than those in patients with Stages 2 and 3 disease $(p=0.003$ compared to Stage 2 and $p=0.006$ compared to Stage 3). The PLR values were significantly lower in patients with Hinchey Stage I disease than those in patients with Stage 2 disease $(p=0.026)$.

\section{DISCUSSION}

In this study, we investigated the utility of complete blood count and inflammatory parameters in the differential diagnosis of diverticulosis and diverticulitis and to determine the prognosis of diverticulitis. We found that in addition to CRP and MPV, the NLR and PLR can be used as diagnostic markers to differentiate between diverticulosis and acute diverticulitis.

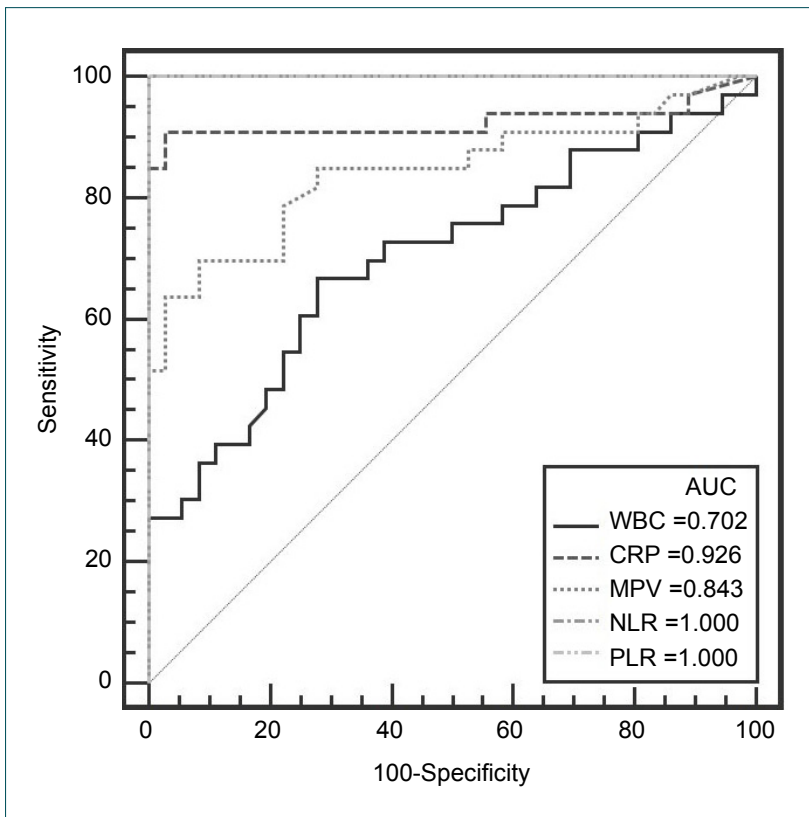

Figure 2. The diagnostic accuracy rates of the various laboratory parameters to distinguish between the diverticulitis and control groups.

The NLR is a simple biomarker of inflammation. The total leukocyte and neutrophil counts have historically been used as markers of infection. During inflammation, the neutrophil count increases while the lymphocyte count decreases depending on the neurohormonal mechanisms involved. Therefore, the NLR accurately indicates the underlying inflammatory process. ${ }^{[10,18,19]}$ The benefit of the NLR was previously investigated in various diseases such as malignancies, coronary artery disease, acute appendicitis, acute cholecystitis, acute pancreatitis, and community-acquired infections. ${ }^{[18]}$ Kahramanca et al. ${ }^{[20]}$ found that the pre-operative NLR was a useful parameter to aid in the diagnosis of acute appendicitis and to differentiate between simple and complicated appendicitis. In their study, Reynolds et al. ${ }^{[15]}$ demonstrated that the NLR was a predictive value for surgical intervention in acute diverticulitis. Our study presents new data comparing the accuracy of the NLR with those of other biomarkers in DDC patients. It was determined that the sensitivity (100\%)

Table 5. The distribution of laboratory parameters according to Hinchey's stage

\begin{tabular}{|c|c|c|c|c|}
\hline & \multicolumn{4}{|c|}{ Hinchey's stage } \\
\hline & Stage I & Stage 2 & Stage 3 & Stage 4 \\
\hline White blood cell count $\left(\times 10^{9} / \mathrm{L}\right)$ & $9.65(5.76-13.9)$ & II.6 (8.86-15.5) & $9.98(2.13-19.9)$ & I8.4 (|8.4-|8.4) \\
\hline C-reactive protein (mg/dL) & $7.94(0-52.2)$ & $13.6(0.02-81.1)$ & $29.23(4.43-9.90)$ & $22.6(22.6-22.6)$ \\
\hline Mean platelet volume $(\mathrm{fL})$ & $7.40 \pm 1.13$ & $7.17 \pm 1.05$ & $7.62 \pm 1.99$ & $11.55 \pm 0$ \\
\hline Neutrophil-lymphocyte ratio & $2.32(1.44-3.79)^{*}, \#$ & $5.77(2.04-6.87)$ & $3.62(3.08-10.49)$ & 11.55 (11.55-11.55) \\
\hline Platelet-lymphocyte ratio & $95.69(57.18-203.67)^{\alpha}$ & |63.4| (78.57-298.05) & I5I.53 (66.50-216.33) & $190.14(190.14-190.14)$ \\
\hline
\end{tabular}


of the NLR was very high in the diagnosis of acute diverticulitis. However, the sensitivity (63.64\%) and specificity (72.22\%) and AUC (0.682) of the NLR were low in distinguishing between diverticulitis and diverticulosis.

As expected, the WBC and CRP values were significantly higher in patients with acute diverticulitis than those in the other groups. Hogan et al. ${ }^{[16]}$ showed that inflammatory markers such as the CRP and WBC were useful in the differential diagnosis of complicated and uncomplicated diverticulitis when they were combined with radiological evaluations. In some studies, CRP was reported to be a strong marker to distinguish complicated diverticulitis. ${ }^{[2]}$ However, in our study, it was found that the WBC and CRP were not useful for distinguishing complicated diverticulitis and making the decision for surgical intervention in patients with diverticulitis. Interestingly, the CRP value was significantly higher in the diverticulosis group than that in the control group. In addition, the CRP was a superior inflammatory marker to WBC in distinguishing acute diverticulitis from diverticulosis; its sensitivity was $81.82 \%$, specificity was $83.33 \%$, and the AUC was 0.7793 .

The MPV is an indicator of platelet function and activation that can be easily measured in a routine complete blood count. The MPV has been frequently used in the diagnosis of inflammatory diseases such as acute appendicitis. ${ }^{[22,23]} \mathrm{Al}-$ bayrak et al. ${ }^{[24]}$ found that the MPV levels were significantly lower in patients with acute appendicitis compared to those in the control group. In another study in children with acute appendicitis, Tanrikulu et al. ${ }^{[25]}$ obtained similar results. There are no studies in the literature evaluating the MPV in diverticulitis. In our study, the MPV values were found to be lower in the DDC patients compared to those in the control group, proving for the Ist time that the MPV decreased in both acute diverticulitis and diverticulosis. Although the MPV had a high sensitivity $(84.85 \%)$ in differentiating patients with acute diverticulitis from patients with diverticulosis, the MPV had a low sensitivity $(70 \%)$ in distinguishing patients with diverticulitis from the control group patients. The MPV was found to be a strong marker for distinguishing healthy patients (specificity $91.6 \%$ ). The MPV had no ability to distinguish diverticulitis complications ( $p>0.05$, Table 5).

The PLR, similar to the NLR, has recently become increasingly popular as a prognostic indicator of inflammation in inflammatory and immunologically based diseases. ${ }^{[26-28]}$ In our study, the PLR decreased significantly in patients with diverticular disease. Although the PLR value had high sensitivity in differentiating patients with diverticulitis from control patients (100\%), its sensitivity in distinguishing patients with diverticulosis from diverticulitis was low (30.3\%).

\section{Conclusion}

Because inflammatory markers obtained from the complete blood count can be easily measured without additional costs, they can serve as useful biomarkers for the differential diagnosis of diverticulosis and diverticulitis and to determine the prognosis in diverticulitis patients when used in addition to other tests.

Ethics Committee Approval: This study approved by the Private Medicana Konya Hospital Ethics Committee (Date: 26.19.2019, Decision No: 06).

Peer-review: Internally peer-reviewed.

Authorship Contributions: Concept: Y.T.; Design: S.K., Y.T.; Supervision: Y.T.; Resource: S.K.; Materials: S.K., Y.T.; Data: S.K.; Analysis: S.K.; Literature search: S.K.; Writing: S.K.; Critical revision: Y.T.

Conflict of Interest: None declared.

Financial Disclosure: The authors declared that this study has received no financial support.

\section{REFERENCES}

1. Nguyen GC, Sam J, Anand N. Epidemiological trends and geographic variation in hospital admissions for diverticulitis in the United States. World J Gastroenterol 2011;17:1600-5. [CrossRef]

2. Talabani AJ, Endreseth BH, Edna TH. Major increase in admission-and incidence rates of acute colonic diverticulitis. Int J Color Dis 2014;29:937-45. [CrossRef]

3. Rafferty J, Shellito P, Hyman NH, Buie WD; Standards Committee of American Society of Colon and Rectal Surgeons. Practice parameters for sigmoid diverticulitis. Dis Colon Rectum 2006;49:939-44. [CrossRef]

4. Laméris W, van Randen A, van Gulik TM, Busch OR, Winkelhagen J, Bossuyt PM, et al. A clinical decision rule to establish the diagnosis of acute diverticulitis at the emergency department. Dis Colon Rectum 2010;53:896-904. [CrossRef]

5. Andeweg CS, Mulder IM, Felt-Bersma RJ, Verbon A, van derWilt GJ, van Goor $\mathrm{H}$, et al. Guidelines of diagnostics and treatment of acute left-sided colonic diverticulitis. Dig Surg 2013;30:278-92. [CrossRef]

6. Laurell H, Hansson LE, Gunnarsson U. Acute diverticulitis: Clinical presentation and differential diagnostics. Colorectal Dis 2007;9:496-502.

7. Kargın S, Çakır M, Gündeș E, Yavuz Y, Esen HH, İyisoy MS. Relationship of preoperative neutrophil lymphocyte ratio with prognosis in gastrointestinal stromal tumors. Turk J Surg 2015;31:61-4. [CrossRef]

8. Kelly ME, Khan A, Riaz M, Bolger JC, Bennani F, Khan W, et al. The utility of neutrophil-to-lymphocyte ratio as a severity predictor of acute appendicitis, length of hospital stay and postoperative complication rates. Dig Surg 2015;32:459-63. [CrossRef]

9. Azab B, Jaglall N, Atallah JP, Lamet A, Raja-Surya V, Farah B, et al. Neutrophil-lymphocyte ratio as a predictor of adverse outcomes of acute pancreatitis. Pancreatology 2011;11:445-52. [CrossRef]

10. Tamhane UU, Aneja S, Montgomery D, Rogers EK, Eagle KA, Gurm HS. Association between admission neutrophil to lymphocyte ratio and outcomes in patients with acute coronary syndrome. Am J Cardiol 2008;102:653-7. [CrossRef]

11. Yamanaka T, Matsumoto S, Teramukai S, Ishiwata R, Nagai Y, Fukushi$\mathrm{ma}$ M. The baseline ratio of neutrophils to lymphocytes is associated with patient prognosis in advanced gastric cancer. Oncology 2007;73:215-20.

12. Tursi A, Brandimarte G, Giorgetti G, Elisei W, Maiorano M, Aiello F. The clinical Picture of uncomplicated versus complicated diverticulitis of the colon. Dig Dis Sci 2008;53:2474-9. [CrossRef] 
13. Kaser SA, Fankhauser G, Glauser PM, Toia D, Maurer CA. Diagnostic value of inflammation markers in predicting perforation in acute sigmoid diverticulitis. World J Surg 2010;34:2717-22. [CrossRef]

14. Tursi A, Elisei W, Brandimarte G, Giorgetti GM, Aiello F. Predictive value of serologic markers of degree of histologic damage in acute uncomplicated colonic diverticulitis. J Clin Gastroenterol 2010;44:702-6. [CrossRef]

15. Reynolds IS, Heaney RM, Khan W, Khan IZ, Waldron R, Barry K. The utility of neutrophil to lymphocyte ratio as a predictor of intervention in acute diverticulitis. Dig Surg 2017;34:227-32. [CrossRef]

16. Hogan J, Sehgal R, Murphy D, O’Leary P, Coffey JC. Do inflammatory indices play a role in distinguishing between uncomplicated and complicated diverticulitis? Dig Surg 2017;34:7-11. [CrossRef]

17. Hinchey EJ, Schaal PG, Richards GK. Treatment of perforated diverticular disease of the colon. Adv Surg 1978;12:85-109.

18. de Jager CP, van Wijk PT, Mathoera RB, de Jongh-Leuvenink J, van der Poll T, Wever PC. Lymphocytopenia and neutrophil-lymphocyte count ratio predict bacteremia better than conventional infection markers in an emergency care unit. Crit Care 2010;14:R192. [CrossRef]

19. Wyllie DH, Bowler IC, Peto TE. Relation between lymphopenia and bacteraemia in UK adults with medical emergencies. J Clin Pathol 2004;57:950-5. [CrossRef]

20. Kahramanca S, Ozgehan G, Seker D, Gökce EI, Seker G, Tunç G, et al. Neutrophil-to-lymphocyte ratio as a predictor of acute appendicitis. Ulus Travma Acil Cerrahi Derg 2014;20:19-22. [CrossRef]

21. Tan JP, Barazanchi AW, Singh PP, Hill AG, Maccormick AD. Predictors of acute diverticulitis severity: A systematic review. Int J Surg
2016;26:43-52. [CrossRef]

22. Torbati SS, Guss DA. Impact of helical computed tomography on the outcomes of emergency department patients with suspected appendicitis. Acad Emerg Med 2003;10:823-9. [CrossRef]

23. Orr RK, Porter D, Hartman D. Ultrasonography to evaluate adults for appendicitis: Decision making based on meta-analysis and probabilistic reasoning. Acad Emerg Med 1995;2:644-50. [CrossRef]

24. Albayrak Y, Albayrak A, Albayrak F, Yildirim R, Aylu B, Uyanik A, et al. Mean platelet volume: $A$ new predictor in confirming acute appendicitis diagnosis. Clin Appl Thromb Hemost 2011;17:362-6. [CrossRef]

25. Tanrikulu CS, Tanrikulu Y, Sabuncuoglu MZ, Karamercan MA, Akkapulu N, Coskun F. Mean platelet volume and red cell distribution width as a diagnostic marker in acute appendicitis. Iran Red Crescent Med J 2014;16:e10211. [CrossRef]

26. Wang Q, Ma J, Jiang Z, Ming L. Prognostic value of neutrophil-to-lymphocyte ratio and platelet-to-lymphocyte ratio in acute pulmonary embolism: A systematic review and meta-analysis. Int Angiol 2018;37:411.

27. Martins GC, de Oliveira Melo Júnior OA, Botoni LS, Nogueira MM, da Costa Val AP, Blanco BS, et al. Clinical-pathological and immunological biomarkers in dogs with atopic dermatitis. Vet Immunol Immunopathol 2018;205:58-64. [CrossRef]

28. Kawashima H, Utsugi A, Shibamiya A, Iida K, Mimura N, Ohashi H, et al. Consideration concerning similarities and differences between $\mathrm{AN}$ CA-associated vasculitis and IgG-4-related diseases: Case series and review of literature. Immunol Res 2019;67:99-107. [CrossRef]

\section{ORIJIINAL ÇALIŞMA - ÖZET}

\section{Akut divertikülitte enflamatuvar parametrelerin tanısal ve prognostik önemi: Geriye dönük kohort çalışması \\ Dr. Süleyman Kargın, Dr. Yusuf Tanrıkulu \\ KTO Karatay Üniversitesi Tıp Fakültesi, Genel Cerrahi Anabilim Dalı, Konya}

AMAÇ: Akut divertikülit tanısı ve şiddetinin belirlenmesinde optimum biyokimyasal veya hematolojik belirteç henüz belirlenememiştir. Bu çalışmada, akut divertikülit tanısında ve hastalığın şiddetinde nötrofil-lenfosit oranı gibi hematolojik parametrelerin etkinliğinin karşılaştııımasını amaçladık. GEREÇ VE YÖNTEM: Divertiküler hastalık tanısı alan 69 hasta (akut divertikülit ve divertiküloz alt grupları) ve kontrol grubunda 36 hasta çalışmaya dahil edildi. Tanı anında yapılan biyokimyasal analizler arasında beyaz küre sayısı, ortalama trombosit hacmi, nötrofil sayısı, trombosit sayısı ve C-reaktif protein değerleri çalışmaya alındı. Nötrofil-lenfosit oranı ve trombosit-lenfosit oranı hesaplandı. Akut divertikülit grubunda abdominal tomografi bulgularına dayalı Hinchey sınıflamasına göre dört gruba ayrıldı.

BULGULAR: Akut divertikülit ve divertikülozis gruplarındaki ortalama trombosit-lenfosit oranı, kontrol grubuna göre anlamlı olarak daha düşüktü $(p<0.05)$. Akut divertikülit ve divertikülozis ayrımında en iyi duyarlıık ve özgüllük değerleri nötrofil-lenfosit oranı 2.78 ve üzeri için kestirim (cut-off) değerinde \%63.64 ve \%72.22 ve trombosit-lenfosit oranı 87.46 ve üzeri için kestirim değerinde \%30.30 ve \%86. I I olarak bulundu. Akut divertikülit ve kontrol grubu ayrımında en iyi duyarlıık ve özgüllük değerleri, nötrofil-lenfosit oranı I I. 55 ve üzeri kestirim değerinde sırasıyla \% I00 ve \%0 iken trombosit-lenfosit oranı 12.28 ve üzeri kestirim değerinde ise sırasıyla \% I00 ve \% 100 olarak tespit edildi. Nötrofil-lenfosit oranı Hinchey evre I'de evre 2 ve 3'e göre anlamlı derecede düşüktü (sırasıyla, $p=0.003, p=0.006$ ).

TARTIŞMA: Nötrofil-lenfosit oranı ve trombosit-lenfosit oranı gibi hematolojik parametreler divertiküloz ve divertikülitin ayırıcı tanısı ve divertikülitte prognozu belirlemek için yararlı biyomarker olarak kullanılabilir.

Anahtar sözcükler: Akut divertikülit; divertikülozis; nötrofil-lenfosit oranı; trombosit-lenfosit oranı.

Ulus Travma Acil Cerrahi Derg 2021;27(3):325-330 doi: 10.14744/tjtes.2020.92068 